спрямуванням. Актуальні проблеми державного управління, педагогіки ma психологї̈: збірник наукових праць Херсонського національного технічного університету. Херсон: Грінь Д. С., 2014, Вип. 1 (10). C. $107-110$.

5. Про організацію вивчення гуманітарних дисциплін за вільним вибором студента. Наказ Міністерства Освіти і Науки України № 642 від 09.07.2009 p. - mon.gov.ua>images/newstmp/2010/25_08/831.doc. (дата звернення 12.07.2021).

6. Професійний стандарт на групу професій «Викладачі закладів вищої освіти», затверджений 23 березня 2023 року. URL: https://mon.gov.ua/storage/app/media/pto/standarty/2021/03/25/Standart\%20 na\%20hrupu\%20profesiy_Vykladachi\%20zakladiv\%20vyshchoyi\%20osvity _25.03.pdf (дата звернення 12.07.2021).

7. Румянцева И.М. Психотерапия на стыке наук: интегративный лингво-психологический тренинг в обучении иноязычной речи. Психологічні перспективи: Волин.нац.ун-т ім. Лесі Українки; Ін-т соц. та політ.психології АПН України. Луцьк, 2011ю - Вип.18 - С. 220-229.

DOI https://doi.org/10.30525/978-9934-26-146-6-31

\title{
АНАЛІЗ СКЛАДОВИХ МОДЕЛІ РОЗВИТКУ РУХОВИХ ЯКОСТЕЙ СТУДЕНТОК ЗАКЛАДІВ ВИЩОЇ ОСВІТИ В УМОВАХ ПРОФЕСІЙНОӦ ПІДГОТОВКИ НА АКМЕОЛОГІЧНИХ ЗАСАДАХ
}

\author{
Самохвалова I. Ю. \\ аспірант \\ Сумський державний педагогічний університет імені А. С. Макаренко \\ Харченко С. М. \\ кандидат педагогічних наук, \\ доиент кафедри фізичного виховання \\ Сумський національний аграрний університет \\ м. Суми, Украӥна
}

Стан здоров'я населення у сучасному світі $\epsilon$ показником рівня розвитку суспільства. Наслідки недостатньої рухової активності молодих жінок обумовлюють виникнення порушень в стані опорнорухового апарату, серцево-судинної, дихальної, ендокринної, травної 
систем, а також надлишкової маси тіла, депресій, нервово-психічних розладів, тощо. За даними дослідників, дефіцит рухової активності дівчат $\epsilon$ найбільш актуальним питанням на тлі демографічних проблем, які характеризуються негативними показниками приросту населення [3].

Ми підтримуємо думку провідних дослідників [1;4] про те, що рекомендації будь-яких оздоровчих систем для жінок повинні базуватися на індивідуальному підході, що сприятиме розвитку професійно важливих рухових якостей, формуванню стійкої звички до здорового способу життя та їх професійному зростанню[2].

Мета статті полягає у висвітленні основних складових моделі розвитку рухових якостей студенток закладів вищої освіти в умовах професійної підготовки на акмеологічних засадах.

Для побудови моделі розвитку рухових якостей студенток ми спирались на наступні принципи:

- оздоровчої спрямованості (фізичні навантаження підбираються відповідно до можливостей студенток, застосовуються медико біологічні методи контролю);

- індивідуалізації (застосування індивідуальної діагностики рівня фізичної підготовленості, вивчення особливостей протікання біологічних циклів та підбір відповідних програм занять);

- свідомості та активності (індивідуальний підхід до тренувального процесу, участь самих студенток, можливість оцінки власних результатів це посилює мотивацію до занять);

- адаптаційно збалансованої динаміки навантажень (корекція засобів та методів тренування, допустимих у межах окремого тренувального заняття у відповідності 3 поточними завданнями індивідуального оздоровчого процесу);

- системності і систематичності (основа змістового компонента i процесуальної частини побудови занять, неодмінна умова для розширення функціональних можливостей, поліпшення фізичної підготовленості та розвитку рухових якостей студенток).

Структура моделі розвитку рухових якостей студенток закладів вищої освіти містить такі компоненти: цільовий, базовий, методичний i контролюючий

Цільовий компонент моделі розвитку рухових якостей в умовах професійної підготовки на акмеологічних засадах містить мету й завдання, що спрямовані на формування у студенток закладів вищої освіти різних профілів ціннісного ставлення до здоров'я, відповідального ставлення до здорового способу життя, усвідомлення ними потреби розвитку рухових якостей для професійного зростання. 
Реалізація провідної мети і окреслених завдань передбачає сприяння ефективному розвитку рухових якостей студенток закладів вищої освіти різних профілів в умовах професійної підготовки, як наслідок, оволодіння життєво та професійно необхідними навичками та вміннями; формуванню мотивації до занять фізичної культури, здорового способу життя.

Базовий компонент визначає гендерні особливості розвитку рухових якостей студенток: вік, рівень фізичного стану, рівень фізичної підготовленості та індивідуальних морфологічних особливостей .

Ця складова моделі конкретизує фактори, які здійснюють вплив на розвиток рухових якостей студенток на акмеологічних засадах в умовах професійної підготовки: ціннісне ставлення до особистого здоров'я; специфіка майбутньої професійної діяльності; особливості фізичної працездатності, професійної рухової активності та необхідний рівень фізичного здоров'я майбутніх фахівців; мотивації до рухової діяльності здобувачів вищої освіти у процесі розвитку і вдосконалення рухових якостей.

Методичний компонент моделі розвитку рухових якостей студенток закладів вищої освіти в умовах професійної підготовки на акмеологічних засадах розкриває особливості реалізації іiї форм методів та засобів. Серед форм організації освітньої діяльності визначаються практичні заняття 3 фізичного виховання, навантаження на яких підбирається 3 урахуванням індивідуального оваріально - менструального циклу студенток. Провідними засобами фізичного виховання студенток виступають комплекси вправ для розвитку професійно важливих рухових якостей, щоденники здоров'я, технології цифрового навчання. Зміст фізичного виховання розширюється через організацію науково популярних лекцій 3 проблем здоров'язбереження; можливих негативних впливів умов виробництва на стан здоров'я фахівців різних спеціальностей.

Контролюючий компонент моделі розвитку рухових якостей студенток закладів вищої освіти на акмеологічних засадах в умовах професійної підготовки передбачає контроль та аналіз показників розвитку рухових якостей здобувачів вищої освіти, рівня фізичного та психоемоційного здоров'я.

\section{Література:}

1. Мартинова Н. П. Сучасний погляд на проблему розвитку рухових якостей студенток закладів вищої освіти. Науковий часопис НПУ імені Н.П. Драгоманова. Випуск 3. К 110, 2019. С. 349 - 353. 
2. Пилипей Л. П. Моделювання ППФП студентів ВНЗ. Слобожсанський науково-спортивний вісник. Харків, 2009. № 4. C. $26-31$.

3. Редькіна М. А. Особливості індивідуальної рухової активності студентів педагогічних спеціальностей. Гірська школа Українських Kapnam, 2019. № 21. С. $78-81$.

4. Редько Т. М., Франчук О. П., Авдієнко Н. В. Педагогічні умови розвитку рухових якостей студенток вищого навчального закладу. Біомеханічні, педагогічні, психологічні, аспекти фізичного виховання та cnopmy, 2012. № 102. T. 1. C. $310-312$.

DOI https://doi.org/10.30525/978-9934-26-146-6-32

\title{
СУЧАСНІ ТЕНДЕНЦІЇ РОЗВИТКУ КРЕАТИВНОСТІ ІНТЕЛЕКТУАЛЬНО ОБДАРОВАНИХ УЧНІВ У ЗАКЛАДАХ ЗАГАЛЬНОЇ СЕРЕДНЬОЇ ОСВІТИ
}

\author{
Софіюк C. B. \\ учитель украӥнської мови та літератури \\ Житомирська загальноосвітня школа I - III ступенів № 22 імені \\ Василя Михайловича Кавуна \\ м. Житомир, Україна
}

У XXI столітті конкурентоспроможність людини, їі успіх у житті й побудові кар'єри визначається не кількістю накопиченої інформації (чистих знань), а сформованістю компетентностей, що виявляється у здатності успішно соціалізуватися, реалізувати власні цілі, повноцінно жити в умовах сучасного глобалізованого інформаційного світу.

Нині перед українським суспільством загалом та освітянською спільнотою зокрема постали надзвичайно важливі питання пошуку перспективних інноваційних технологій навчання та підходів, які забезпечуватимуть успішне й повноцінне майбутнє, професійний розвиток здобувачів освіти в умовах сьогодення. Так, згідно з Концепцією реалізації державної політики у сфері реформування загальної середньої освіти «Нова українська школа» на період до 2029 року, випускник має бути особистістю, патріотом та інноватором - людиною, яка здатна «змінювати навколишній світ, розвивати економіку, конкурувати на ринку праці й навчатися впродовж життя» [3]. 